九州大学学術情報リポジトリ

Kyushu University Institutional Repository

Effect of Biochar Derived from Coffee Sludge on Growth of Chinese Cabbage (Brassica campestris L. ssp. pekinensis) in Field Soil and Bed Soil

SONG, Hyeon-Ji

Department of Bio-Environmental Chemistry, College of Agriculture and Life science, Chungnam National University | Science for Bioproduction Environment, Faculty of Agriculture, Kyushu University

LEE, Jae-Han

Department of Bio-Environmental Chemistry, College of Agriculture and Life science, Chungnam National University

KIM, Su-Hun

Department of Bio-Environmental Chemistry, College of Agriculture and Life science, Chungnam National University

LEE, Ho-Cheol

4EN, A-504, 32, Digital-ro 9-gil, Geumcheon-gu

他

https://doi.org/10.5109/1911212

出版情報：九州大学大学院農学研究院紀要. 63 (1)，pp.131-137，2018-02-27. Faculty of Agriculture, Kyushu University

バージョン :

権利関係 : 


\title{
Effect of Biochar Derived from Coffee Sludge on Growth of Chinese Cabbage (Brassica campestris L. ssp. pekinensis) in Field Soil and Bed Soil
}

\author{
Hyeon-Ji SONG ${ }^{1}$, Jae-Han LEE ${ }^{1}$, Su-Hun KIM11, Ho-Cheol LEE ${ }^{2}$, \\ Yoshiyuki SHINOGI ${ }^{3}$ and Taek-Keun $\mathrm{OH}^{1 *}$ \\ Science for Bioproduction Environment, Faculty of Agriculture, Kyushu University, \\ Hakozaki 6-10-1, Higashi-ku, Fukuoka city 812-8581, Japan \\ (Received October 31, 2017 and accepted November 20, 2017)
}

\begin{abstract}
Biochar is the carbon solid produced through the pyrolysis of biomass from organic sources such as agricultural waste, animal manure, and sludge under limited or anaerobic conditions. It is known to function as a soil amendment, affecting water and nutrient retention, soil acidification, and active growth of soil microorganisms. This experiment was conducted to evaluate the application of biochar on the growth characteristics of Chinese cabbage at Chungnam National University in Daejeon, Korea from December 28, 2016 to February 22, 2017. Coffee sludge was used to produce biochar through pyrolysis, which was then applied at $0 \%, 2 \%$, and $5 \%$ to field soil and bed soil. In field soil, the Chinese cabbage with $5 \%$ treatment of coffee sludge biochar had the highest fresh weight (116.46 $\pm 1.3 \mathrm{~g} /$ plant) and as the content of biochar increased, the number of leaves that appeared also increased. In bed soil, the Chinese cabbage with $2 \%$ coffee sludge biochar treatment had the highest fresh weight (209.35 $\pm 13.8 \mathrm{~g} / \mathrm{plant})$. Compared to the control, biochar treatments resulted in increased number of leaves, leaf length, and leaf width. The organic matter in field soil under $5 \%$ coffee sludge biochar treatment was $7.1 \pm 0.44 \%$, whereas it was $1.0 \pm 0.14 \%$ in the control. The organic matter in bed soil under $5 \%$ coffee sludge biochar treatment was $31.8 \pm 5.86 \%$, whereas it was $25.9 \pm 6.00 \%$ in the control. An increase in the total nitrogen of both field soil and bed soil was observed when the biochar content increased. Chinese cabbage grew better in bed soil with coffee sludge biochar than in field soil because of the optimal $\mathrm{pH}$ conditions. Our results support the application of biochar for increased growth of Chinese cabbage, particularly in bed soil.
\end{abstract}

Key words: Biochar, Coffee sludge, Chinese cabbage, Bed soil

\section{INTRODUCTION}

The soil in Korea is acidic and has a low cation exchange capacity (CEC), because it is composed of the acidic weathering products of granite and granite gneiss found in about two-thirds of the country (Han et al., 2016). These factors and the use of large amounts of chemical fertilizers have resulted in degeneration of the physical properties of the soil and other adverse effects such as acidification and soil salinity (Lee et al., 2016). Additionally, soil loss caused by heavy rain in the summertime has resulted in low soil fertility (Yoon, 2011). Therefore, application of a soil amendment that aims to improve the chemical, physical, and biological properties of soil along with soil nutrient availability is urgent. In these circumstances, biochar, which semi-permanently saves the carbon in the soil through sequestration is reported to be an effective soil amendment (Oh et al., 2017; Woo, 2013). Further, since biochar has a stable aromatic ring structure that is not decomposed by soil microorganisms or environmental factors, its use in soil amendment can ensure long-term soil management

${ }^{1}$ Department of Bio-Environmental Chemistry, College of Agriculture and Life science, Chungnam National University, Daejeon 305-764, Korea

2 4EN, A-504, 32, Digital-ro 9-gil, Geumcheon-gu, Seoul 08512, Korea

Science for Bioproduction Environment, Faculty of Agriculture, Kyushu University, Hakozaki 6-10-1, Higashi-ku, Fukuoka city 812-8581, Japan

* Corresponding author (E-mail: ok5382@cnu.ac.kr) (T. K. OH)
(Choi, 2012).

Biochar is the carbon solid produced through the pyrolysis of biomass containing organic waste such as agricultural waste, animal manure, and sludge under limited or anaerobic conditions. It is currently utilized for the improvement of soil, mitigation of global warming, and remediation of heavy metal polluted soil. When used for soil improvement, biochar can increase the productivity of crops by improving soil acidity, water and nutrient retention capacity, and air permeability and active growth of soil microorganism (Novak et al., 2009; Spokas et al., 2009; Atkinson et al., 2010; Kwapinski, 2010; Choi, 2012; Gnag and Yoo, 2012; Woo, 2013). When used for mitigation of global warming, biochar has been reported to reduce $\mathrm{N}_{2} \mathrm{O}$ emissions by up to $15 \%$ based on the maximum value and semi-permanently save the carbon in the soil (Yanai et al., 2007). Biochar is used to remediate soil polluted by heavy metals such as $\mathrm{Cu}$ and $\mathrm{Cd}$ because of its high specific surface area (Kim et al., 2012; Koh et al., 2016).

It is advantageous to select a source of biomass readily available in the surrounding environment for the mass-production of biochar. Approximately 9,500 units of coffee shops were recorded in Korea in 2012, and the discarded coffee sludge at $20 \mathrm{~kg}$ per day per shop results in environmental pollution. This means $700,000 \mathrm{t}$ of domestic waste per shop annually (Ha, 2015). This further leads to serious economic losses, with 10billion won spent to handle this waste (WIKITREE, 2015). In Korea, coffee sludge is studied not only as a bulking agent in aerobic composting of wastewater sludge by using bene- 
ficial microorganisms (Ha, 2015) but also as biochar to improve acidic soil (Choi, 2012) and stabilize heavy metals (Kim et al., 2012).

This study aims to investigate the properties of biochar derived from discarded coffee sludge as a soil amendment, as well as its effect on the growth characteristics of Chinese cabbage in field soil and bed soil through pot trials in a greenhouse.

\section{MATERIALS AND METHODS}

\subsection{Materials}

\subsubsection{Medium}

This experiment was conducted at a greenhouse of Chungnam National University in Daejeon, Korea, from December 28, 2016 to February 22, 2017. The crop used this test was Chinese cabbage (Daewon, Dongwon Nongsan. Co., Yongin, Korea). The field soil was obtained from a research farm of Chungnam National University; samples were taken at approximately $10 \mathrm{~cm}$ from the surface and filtered using a $2 \mathrm{~mm}$ sieve. The bed soil (High, Punong. Co., Kyoungju, Korea) was composed of $7 \%$ zeolite, $7 \%$ perlite, $3 \%$ vermiculite, $68 \%$ coco peat, $14.73 \%$ peat moss, $0.243 \%$ fertilizer, $0.004 \%$ wetting agent, and $0.024 \% \mathrm{pH}$ regulator. The field soil sample was collected at a depth of $0-10 \mathrm{~cm}$. It was found to be acidic and relatively low in organic matter (Table 1).

\subsubsection{Generation of Biochar}

The biochar used in this experiment was composed of coffee sludge obtained from coffee shops, and its effect as a soil amendment was investigated. The coffee sludge was dried in an oven for 48 hours at $70^{\circ} \mathrm{C}$ to remove moisture, and sealed in a container with aluminum foil to prevent the flow of oxygen. It was pyrolyzed at $500^{\circ} \mathrm{C}$ for 2 hours in a muffle furnace (1100 Box Frunace, LindBerg/Blue M, Thermo Scientific Inc., USA).

\subsection{Treatments}

Treatments were set up in Wagner pots (1/5000 a, field soil) and in pots (bed soil) of $16.5 \mathrm{~cm}$ height and $20 \mathrm{~cm}$ diameter at the top and $13.5 \mathrm{~cm}$ diameter at the base. Treatment plots of biochar in this experiment were composed of field soil and bed soil at mass ratios of $0 \%$, $2 \%$, and $5 \%$. The trial pots were arranged in a randomized complete block design with three treatments consisting of five replications for Chinese cabbage. The pots were randomly rotated each day to a different position within the block for the duration of the trial. Each pot was provided with $0.15 \mathrm{~L}$ of water, one to two times per day as required depending on the prevailing weather conditions. The amount of applied $\mathrm{N}-\mathrm{P}_{2} \mathrm{O}_{5}-\mathrm{K}_{2} \mathrm{O}$ fertilizer was $21.5-7.8-19.8 \mathrm{~kg} / 10$ a based on Recommendation of the amount of fertilizer for crops (RDA, 2010). Direct seeding was conducted with three seeds per pot and weeded when main leaves of Chinese cabbage numbered two or three.

\subsection{Methods}

\subsubsection{Growth Characteristics}

Observations of plant height, number of leaves, leaf length, leaf width, head height, head girth, fresh weight (shoot, root), and dry weight (shoot, root) of Chinese cabbage (Brassica campestris L. ssp. pekinensis) were recorded based on the Research and Analysis Criteria for crops (RDA, 2012). Each investigation item was recorded after harvest. Leaf length was measured from the collar line to the tip of the longest leaf, and leaf width was assessed at the widest region of the leaf. The number of leaves was determined by the total number of leaves that were more than $1 \mathrm{~cm}$. Dry weight (shoot, root) was determined using a drying oven for at least 24 hours at $70^{\circ} \mathrm{C}$. Chlorophyll was measured using a MINOLTA Chlorophyll meter (SPAD-502, Japan) for the leaves positioned in the center.

\subsubsection{Analysis}

Analysis of field soil, bed soil, and biochar samples was conducted using the method for analysis of soil and manure (Gyeonggi-do Agricultural Research \& Extension Service). Soil samples were collected during the experimental set up and were air-dried for at least $24 \mathrm{~h}$ and then filtered using a $2 \mathrm{~mm}$ sieve. Bed soil samples were also collected during the experimental set up and were air-dried. The yield of biochar was decided by measuring the weight of biochar before and after pyrolysis. The $\mathrm{pH}$ and electrical conductivity (EC) were measured by using a pH meter and EC meter (ORION Versa Star Pro, Thermo Scientific Inc., USA) through electrochemical analysis. The organic matter (OM) and total nitrogen (T-N) were determined using a CN analyzer (Eager 300, Thermo Scientific Inc., USA), and available phosphate was measured using a UV-VIS spectrophotometer (Evolution 300, Thermo Scientific Inc., USA) by using the Lancaster method. The exchangeable cations (K, $\mathrm{Ca}, \mathrm{Mg}$ ) were analyzed using inductively coupled plasma optical emission spectrometry (ICP-OES, GBC Scientific, Australia) after leaching by using $1 \mathrm{~N} \mathrm{NH}_{4} \mathrm{OA}_{\mathrm{C}}$ solution calibrated to $\mathrm{pH} 7.0$.

Table 1. Chemical properties of the field soil and bed soil

\begin{tabular}{|c|c|c|c|c|c|c|c|c|}
\hline \multirow{2}{*}{ Sample } & \multirow{2}{*}{$\begin{array}{c}\mathrm{pH} \\
(1: 5)\end{array}$} & \multirow{2}{*}{ 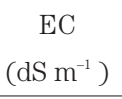 } & $\mathrm{OM}$ & $\mathrm{T}-\mathrm{N}$ & \multirow{2}{*}{$\mathrm{C} / \mathrm{N}$} & \multirow{2}{*}{ Avail. $\mathrm{P}_{2} \mathrm{O}_{5}{ }^{\text {a) }}$} & \multicolumn{2}{|c|}{ Ex. Cations ${ }^{\text {b) }}$} \\
\hline & & & \multicolumn{2}{|c|}{$(\%)$} & & & $\mathrm{Ca}$ & $\mathrm{Mg}$ \\
\hline Field soil & 6.1 & 0.43 & 0.9 & 0.06 & 9 & 217 & 0.53 & 0.14 \\
\hline Bed soil & 6.1 & 5.48 & 23.1 & 0.41 & 33 & 1750 & 1.41 & 0.84 \\
\hline
\end{tabular}

a) Unit, Field soil: $\mathrm{mg} \mathrm{kg}^{-1}$, bed soil: $\mathrm{mg} \mathrm{L}^{-1}$. ${ }^{\text {b) }}$ Unit, Field soil: $\mathrm{cmol}^{+} \mathrm{kg}^{-1}$, bed soil: $\mathrm{cmol}^{+} \mathrm{L}^{-1}$. 


\section{RESULTS AND DISCUSSION}

\subsection{Chemical Properties of Biochar}

The chemical properties of biochar derived from coffee sludge used for this experiment are shown in Table 2. The $\mathrm{pH}$ and EC of coffee sludge biochar were, respectively, 10.0 and $10.9 \mathrm{dS} \mathrm{m}^{-1}$. The alkaline $\mathrm{pH}$ of biochar is the result of alkaline salt separated from the organic matter of biomass during pyrolysis (Ahmad et al., 2012). Further, the EC is judged to be caused by concentrated various salts within the ash due to loss of volatile substances through pyrolysis (Cantrell, 2012). Additional properties include $134.9 \%$ organic matter, $4.4 \%$ total nitrogen, $3992 \mathrm{mg} \mathrm{kg}^{-1}$ available phosphate, and exchangeable $\mathrm{K}, \mathrm{Ca}$, and $\mathrm{Mg}$.

\subsection{Growth Characteristics}

\subsubsection{Chlorophyll and Nitrate}

The chlorophyll and nitrate contents according to the application of coffee sludge biochar in field soil and bed soil collected 57 days after sowing are shown in Table 3. In both field soil and bed soil, as the amounts of coffee sludge biochar applied increased, the chlorophyll and nitrate contents tended to decrease. The chlorophyll content in 5\% coffee sludge biochar (CSB 5\%) in field soil (44.16 $\pm 3.53 \mathrm{SPAD})$ was reduced by $17 \%$ com- pared to that in the control (53.32 $\pm 0.22 \mathrm{SPAD})$. In bed soil, chlorophyll in the CSB 5\% (41.40 $\pm 5.32 \mathrm{SPAD})$ decreased by $16 \%$ compared to that in the control ( $49.28 \pm 3.53 \mathrm{SPAD})$. Additionally, the nitrate content in CSB 5\% in field soil (2267 $\pm 252 \mathrm{ppm})$ decreased by $57 \%$ and in the bed soil $(4167 \pm 513 \mathrm{ppm})$ decreased by $24 \%$ compared to that in the control $(5267 \pm 551 \mathrm{ppm}$ and $5500 \pm 2100 \mathrm{ppm}$, respectively). These results confirm that the application of coffee sludge in Chinese cabbage cultivation is proportional to its effects on chlorophyll and nitrate contents (Hong et al., 2001).

\subsubsection{Growth Characteristics of Chinese Cabbage}

The growth characteristics of Chinese cabbage according to the application of coffee sludge biochar in field soil and bed soil 57 days after sowing are shown in Tables $(4,5)$ and Fig. $(1,2)$. In field soil, the highest shoot fresh weight $\left(116.46 \pm 1.3 \mathrm{~g} \mathrm{plant}^{-1}\right)$ was observed in CSB 5\%, and shoot fresh weight increased by $9 \%$ compared to that in the control $(105.84 \pm 12.2 \mathrm{~g}$ plant $\left.{ }^{1}\right)$. In addition, the number of leaves tended to increase with application of increasing amounts of coffee sludge biochar. In bed soil, the highest shoot fresh weight $\left(209.35 \pm 13.8 \mathrm{~g} \mathrm{plant}^{-1}\right)$ was observed in CSB $2 \%$, and shoot fresh weight increased by $4 \%$ compared to that in the control $\left(200.87 \pm 41.1 \mathrm{~g} \mathrm{plant}^{-1}\right)$. Additionally, the

Table 2. Chemical properties of coffee sludge biochar

\begin{tabular}{|c|c|c|c|c|c|c|c|c|}
\hline \multirow{2}{*}{$\begin{array}{c}\mathrm{pH} \\
(1: 5)\end{array}$} & \multirow{2}{*}{ 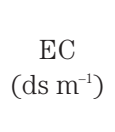 } & \multicolumn{2}{|c|}{$\begin{array}{c}\text { Element content } \\
(\%)\end{array}$} & \multirow[t]{2}{*}{$\mathrm{C} / \mathrm{N}$} & \multirow{2}{*}{$\mathrm{OM}$} & \multirow{2}{*}{$\begin{array}{l}\text { Avail. } \mathrm{P}_{2} \mathrm{O}_{5} \\
\left(\mathrm{mg} \mathrm{kg}^{-1}\right)\end{array}$} & \multicolumn{2}{|c|}{$\begin{array}{l}\text { Ex. cations } \\
\left(\mathrm{cmol} \mathrm{kg}^{-1}\right)\end{array}$} \\
\hline & & $\mathrm{C}$ & $\mathrm{N}$ & & & & $\mathrm{Ca}$ & $\mathrm{Mg}$ \\
\hline 10.0 & 10.9 & 78.3 & 4.4 & 18 & 134.9 & 3992 & 0.3 & 0.3 \\
\hline
\end{tabular}

Table 3. The chlorophyll and nitrate contents in Chinese cabbage according to the application of coffee sludge biochar

\begin{tabular}{|c|c|c|c|c|}
\hline \multirow[b]{2}{*}{ Treatments } & \multicolumn{2}{|c|}{ Soil } & \multicolumn{2}{|c|}{ Bed soil } \\
\hline & $\begin{array}{l}\text { Chlorophyll } \\
\text { (SPAD) }\end{array}$ & $\begin{array}{l}\text { Nitrate } \\
\text { (ppm) }\end{array}$ & $\begin{array}{l}\text { Chlorophyll } \\
\text { (SPAD) }\end{array}$ & $\begin{array}{l}\text { Nitrate } \\
\text { (ppm) }\end{array}$ \\
\hline Control & $53.32 \pm 0.22$ & $5267 \pm 551$ & $49.28 \pm 3.53$ & $5500 \pm 2100$ \\
\hline Coffee sludge biochar 2\% & $50.27 \pm 2.63$ & $3067 \pm 351$ & $43.91 \pm 3.33$ & $4700 \pm 656$ \\
\hline Coffee sludge biochar 5\% & $44.16 \pm 3.53$ & $2267 \pm 252$ & $41.40 \pm 5.32$ & $4167 \pm 513$ \\
\hline
\end{tabular}

Abbreviations: CSB, coffee sludge biochar

Table 4. Growth characteristics of Chinese cabbage according to the application of coffee sludge biochar in field soil

\begin{tabular}{|c|c|c|c|c|c|c|c|c|c|}
\hline \multirow{3}{*}{ Treatments } & \multicolumn{2}{|c|}{ Shoot } & \multicolumn{2}{|c|}{ Root } & \multicolumn{3}{|c|}{ leaf } & \multicolumn{2}{|c|}{ Head } \\
\hline & $\begin{array}{c}\text { fresh } \\
\text { weight }\end{array}$ & $\begin{array}{c}\text { dry } \\
\text { weight }\end{array}$ & $\begin{array}{c}\text { fresh } \\
\text { weight }\end{array}$ & $\begin{array}{c}\text { dry } \\
\text { weight }\end{array}$ & number & length & width & height & girth \\
\hline & \multicolumn{2}{|c|}{$\left(\right.$ g plant $\left.^{-1}\right)$} & \multicolumn{2}{|c|}{$\left(\right.$ g plant $\left.^{-1}\right)$} & (per plant) & \multicolumn{2}{|c|}{$(\mathrm{cm})$} & \multicolumn{2}{|c|}{$(\mathrm{cm})$} \\
\hline Control & $105.84 \pm 12.2$ & $7.53 \pm 0.8$ & $3.62 \pm 0.4$ & $0.43 \pm 0.1$ & $24.67 \pm 2.9$ & $22.91 \pm 1.0$ & $12.48 \pm 1.2$ & $22.00 \pm 1.5$ & $31.00 \pm 1.5$ \\
\hline CSB $2 \%$ & $104.29 \pm 11.4$ & $7.38 \pm 0.9$ & $5.87 \pm 0.8$ & $0.58 \pm 0.1$ & $25.67 \pm 1.5$ & $20.93 \pm 0.4$ & $11.49 \pm 0.4$ & $19.33 \pm 0.8$ & $33.70 \pm 0.9$ \\
\hline CSB 5\% & $116.46 \pm 1.3$ & $9.56 \pm 3.6$ & $7.20 \pm 3.2$ & $0.69 \pm 0.4$ & $27.33 \pm 2.1$ & $20.89 \pm 1.5$ & $11.39 \pm 0.4$ & $19.37 \pm 2.0$ & $34.10 \pm 0.7$ \\
\hline
\end{tabular}


Table 5. Growth characteristics of Chinese cabbage according to the application of coffee sludge biochar in bed soil

\begin{tabular}{|c|c|c|c|c|c|c|c|c|c|}
\hline \multirow{3}{*}{ Treatments } & \multicolumn{2}{|c|}{ Shoot } & \multicolumn{2}{|c|}{ Root } & \multicolumn{3}{|c|}{ leaf } & \multicolumn{2}{|c|}{ Head } \\
\hline & $\begin{array}{c}\text { fresh } \\
\text { weight }\end{array}$ & $\begin{array}{c}\text { dry } \\
\text { weight }\end{array}$ & $\begin{array}{l}\text { fresh } \\
\text { weight }\end{array}$ & $\begin{array}{c}\text { dry } \\
\text { weight }\end{array}$ & & length & width & height & girth \\
\hline & \multicolumn{2}{|c|}{$\left(\right.$ g plant $^{-1}$ ) } & \multicolumn{2}{|c|}{$\left(\right.$ g plant $^{-1}$ ) } & (per plant) & \multicolumn{2}{|c|}{$(\mathrm{cm})$} & \multicolumn{2}{|c|}{$(\mathrm{cm})$} \\
\hline Control & $200.87 \pm 41.1$ & $10.17 \pm 2.3$ & $5.36 \pm 0.6$ & $0.58 \pm 0.1$ & $32.33 \pm 3.2$ & $25.19 \pm 1.6$ & $14.82 \pm 1.5$ & $24.30 \pm 1.2$ & $43.50 \pm 3.5$ \\
\hline CSB $2 \%$ & $209.35 \pm 13.8$ & $11.62 \pm 0.7$ & $6.75 \pm 0.8$ & $0.84 \pm 0.1$ & $32.67 \pm 3.2$ & $27.04 \pm 1.4$ & $15.68 \pm 0.6$ & $26.43 \pm 0.8$ & $40.33 \pm 0.8$ \\
\hline CSB 5\% & $188.99 \pm 12.6$ & $10.68 \pm 1.2$ & $7.22 \pm 2.1$ & $0.81 \pm 0.1$ & $32.67 \pm 2.3$ & $26.54 \pm 1.1$ & $15.54 \pm 0.6$ & $25.50 \pm 2.0$ & $37.63 \pm 3.1$ \\
\hline
\end{tabular}

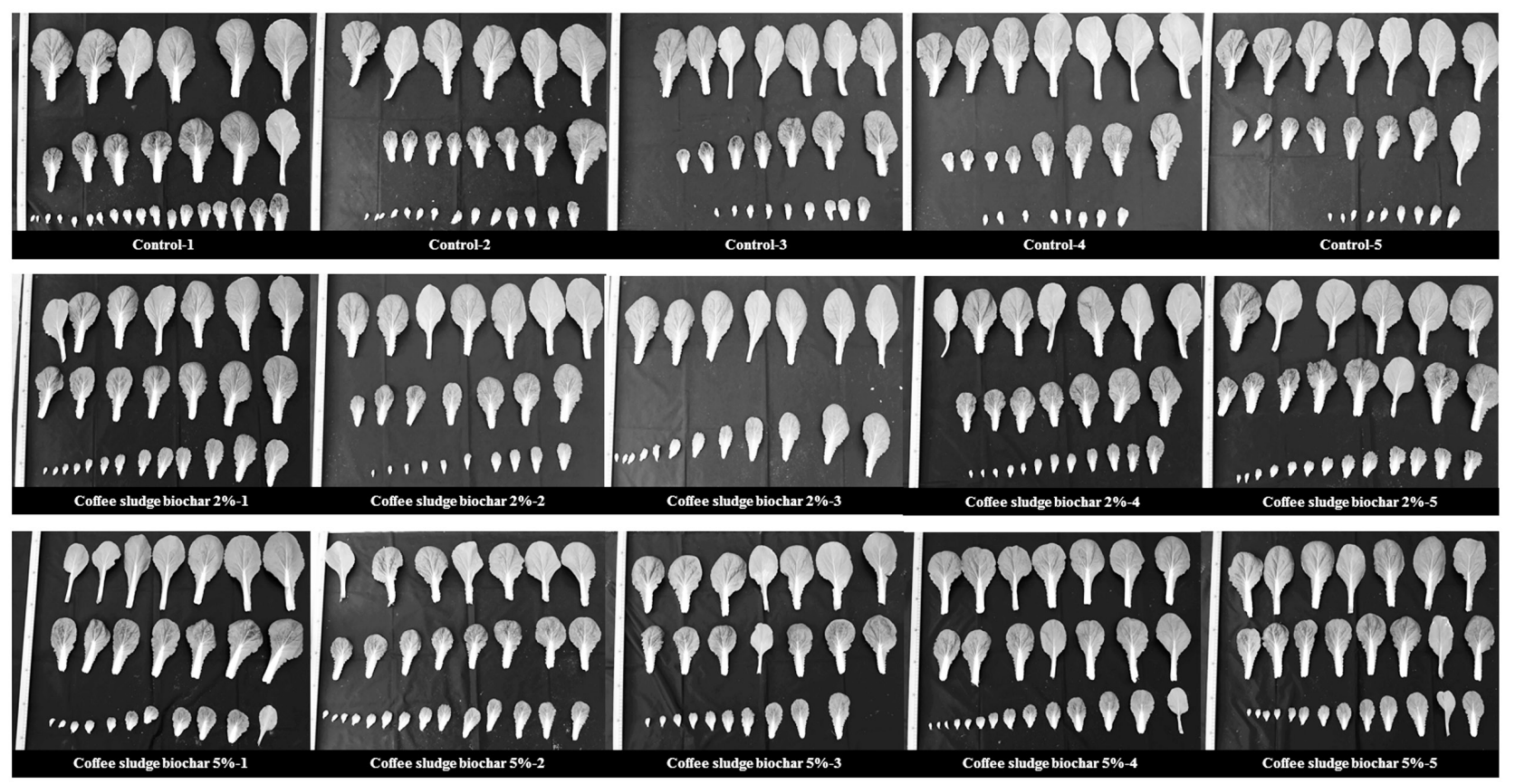

Fig. 1. Growth characteristics of Chinese cabbage according to the application of coffee sludge biochar in field soil.

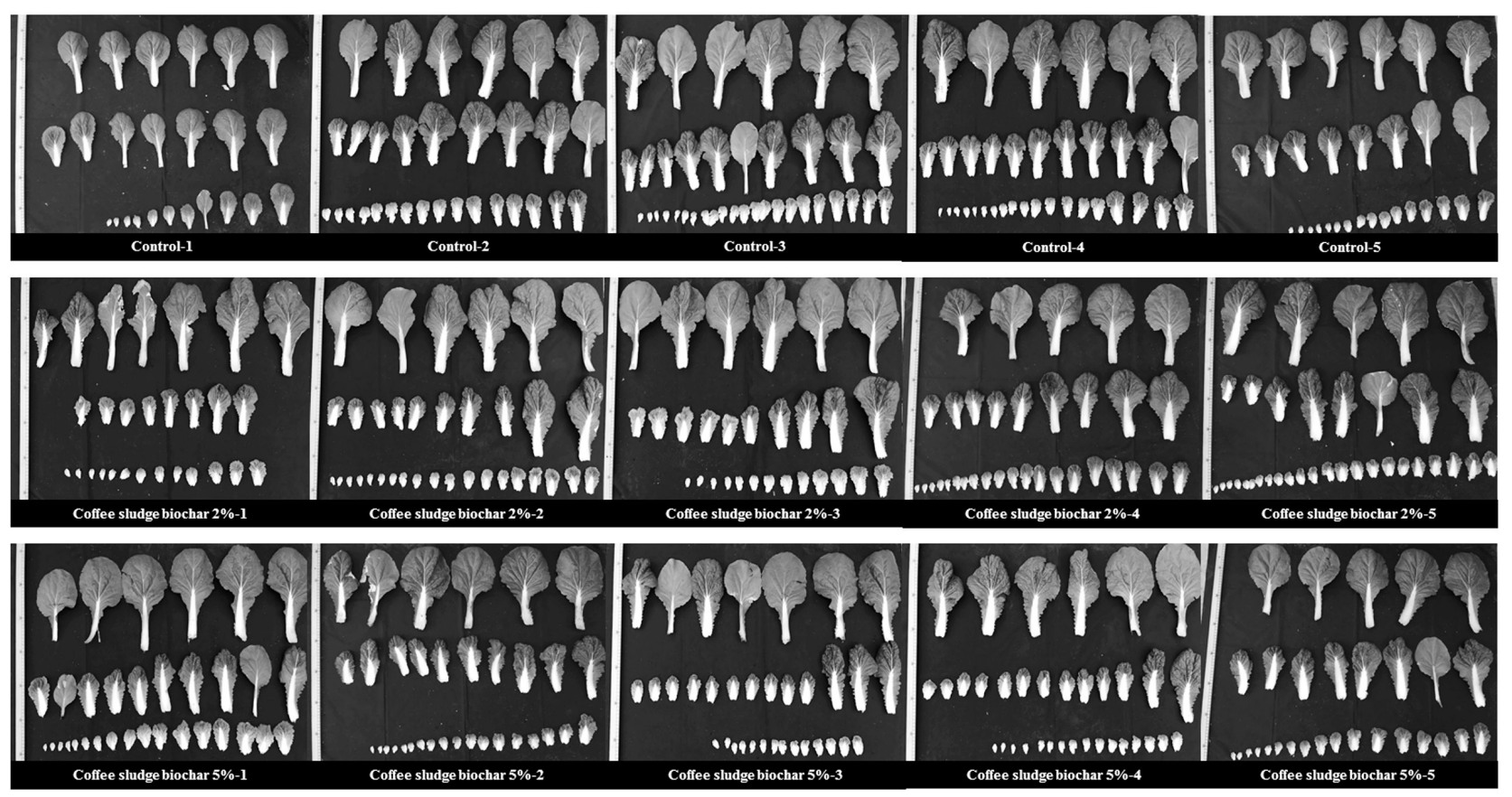

Fig. 2. Growth characteristics of Chinese cabbage according to the application of coffee sludge biochar in bed soil. 
number of leaves, leaf length, and leaf width in biochar treatments was more than those of the control. It should be noted that Chinese cabbage in biochar treatments had more water content than that in the control based on the differences in shoot fresh and dry weights because of biochar characteristics such as high specific surface area and pore volume. In addition, the root fresh weight in both field soil and bed soil tended to increase with application of increasing amounts of biochar. This was considered to be caused by an increase in the permeability of roots promoted by the biochar characteristics explained above. The growth characteristics of Chinese cabbage such as shoot fresh weight, number of leaves, leaf length, leaf width, and head height was higher in bed soil than in field soil. This outcome was achieved by the optimal $\mathrm{pH}$ levels (6.0-6.5) for the growth of Chinese cabbage in bed soil due to the applied coffee sludge biochar. From these results, it is clear that biochar application improves the growth of Chinese cabbage, particularly in bed soil.

\subsection{Chemical Properties of Field Soil and Bed soil}

The chemical properties of field soil and bed soil according to the application of coffee sludge biochar are shown in Tables 6 and 7. The pH of field soil in CSB 2\% and CSB 5\% treatments was 7.1 and 7.8, respectively, which were higher than that of the control $(\mathrm{pH} 6.0)$ and exceeded the optimal pH for Chinese cabbage (6.0-6.5). The $\mathrm{pH}$ of bed soil in CSB 2\% and CSB 5\% treatments was 6.4 and 6.5 , respectively, whereas that of the control was 6.0. Thus, application of coffee sludge biochar can improve soil acidity, as well as lower the heavy metal contents in soil, thereby regulating their uptake by plants (Lim et al., 2015, Koh et al., 2016). In addition, coffee sludge biochar can be used for consistent management of the soil because biochar has as a stable aromatic ring structure (Choi, 2012). A tendency for the EC to increase was noted in field soil and bed soil treated with coffee sludge biochar compared to the control. Nevertheless, the EC value was lower than the value $\left(2.0 \mathrm{dS} \mathrm{m}^{-1}\right)$ that negatively affects the growth of Chinese cabbage. The available phosphate in coffee sludge biochar treatments in both field soil and bed soil was higher than that in the control. As coffee sludge biochar absorbs large amounts of phosphorous comparison to that by general organic matter, it contributes to a more favorable role when crops absorb phosphorus. (Woo, 2013). The organic matter and total nitrogen contents in both field soil and bed soil treated with coffee sludge biochar were higher than those in the control and were within the appropriate standard for cultivation of Chinese cabbage. Soils with low organic matter not only have low nutrient holding capacity but can also cause growth disorders through the harmful action of heavy metal ions. The application of coffee sludge biochar is a possible solution, because it can maintain the optimal organic matter for growing conditions. The cation exchange capacity is expressed as a figure of how fine particles of soil have a negative charge. The fine particles of soil are called soil colloids and these have a negative charge whereas, nutrient components needed to grow crops have a positive charge. Therefore, these tend to be bound with each other. In other words, the high cation exchange capacity means that the ability to retain the nutrients that crops can use is high. The exchangeable cations that have important mean of cation exchange capacity are shown Table 6 and 7. The exchangeable cation in coffee sludge biochar treatments in both field soil and bed soil was slightly decreased compared to control but it didnangeable a significant difference. The changeable calcium content in coffee sludge biochar treatments in field soil was only about $8 \%\left(0.47-0.48 \mathrm{cmol}^{+} \mathrm{kg}^{-1}\right)$ of optimal figure $\left(5-7 \mathrm{cmol}^{+} \mathrm{kg}^{-1}\right)$. Also, the changeable magnesium content in coffee sludge biochar treatments in field soil was only about $7 \%\left(0.13 \mathrm{cmol} \mathrm{\textrm {kg } ^ { - 1 }}\right)$ of optimal figure $(1.5-$ $\left.2.5 \mathrm{cmol}^{+} \mathrm{kg}^{-1}\right)$.

Table 6. Chemical properties of field soil after harvesting Chinese cabbage

\begin{tabular}{|c|c|c|c|c|c|c|c|c|}
\hline \multirow[t]{2}{*}{ Treatments } & \multirow{2}{*}{$\begin{array}{c}\mathrm{pH} \\
(1: 5)\end{array}$} & \multirow{2}{*}{$\begin{array}{c}\mathrm{EC} \\
\left(\mathrm{dS} \mathrm{m}^{-1}\right)\end{array}$} & $\mathrm{OM}$ & \multirow[t]{2}{*}{$\mathrm{T}-\mathrm{N}$} & \multirow[t]{2}{*}{$\mathrm{C} / \mathrm{N}$} & \multirow{2}{*}{$\begin{array}{c}\text { Avail. } \mathrm{P}_{2} \mathrm{O}_{5} \\
\left(\mathrm{mg} \mathrm{kg}^{-1}\right)\end{array}$} & \multicolumn{2}{|c|}{$\begin{array}{l}\text { Ex. cations } \\
\left(\mathrm{cmol}^{+} \mathrm{kg}^{-1}\right)\end{array}$} \\
\hline & & & $(\%)$ & & & & $\mathrm{Ca}$ & $\mathrm{Mg}$ \\
\hline Control & $6.0 \pm 0.13$ & $0.38 \pm 0.06$ & $1.0 \pm 0.14$ & $0.1 \pm 0.01$ & $9 \pm 0.50$ & $244 \pm 21.72$ & $0.55 \pm 0.01$ & $0.14 \pm 0.02$ \\
\hline CSB $2 \%$ & $7.1 \pm 0.16$ & $0.44 \pm 0.11$ & $3.7 \pm 0.56$ & $0.2 \pm 0.02$ & $14 \pm 0.19$ & $386 \pm 74.98$ & $0.48 \pm 0.01$ & $0.13 \pm 0.01$ \\
\hline CSB 5\% & $7.8 \pm 0.05$ & $0.45 \pm 0.02$ & $7.1 \pm 0.44$ & $0.3 \pm 0.02$ & $15 \pm 0.82$ & $444 \pm 51.89$ & $0.47 \pm 0.02$ & $0.13 \pm 0.01$ \\
\hline
\end{tabular}

Table 7. Chemical properties of bed soil after harvesting Chinese cabbage

\begin{tabular}{|c|c|c|c|c|c|c|c|c|}
\hline \multirow[t]{2}{*}{ Treatments } & \multirow{2}{*}{$\begin{array}{c}\mathrm{pH} \\
(1: 5)\end{array}$} & \multirow{2}{*}{ 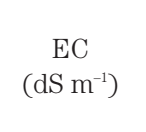 } & $\mathrm{OM}$ & \multirow[t]{2}{*}{$\mathrm{T}-\mathrm{N}$} & \multirow[t]{2}{*}{$\mathrm{C} / \mathrm{N}$} & \multirow{2}{*}{$\begin{array}{c}\text { Avail. } \mathrm{P}_{2} \mathrm{O}_{5} \\
\left(\mathrm{mg} \mathrm{L}^{-1}\right)\end{array}$} & \multicolumn{2}{|c|}{$\begin{array}{l}\text { Ex. cations } \\
\left(\mathrm{cmol}^{+} \mathrm{kg}^{-1}\right)\end{array}$} \\
\hline & & & $(\%)$ & & & & $\mathrm{Ca}$ & $\mathrm{Mg}$ \\
\hline Control & $6.0 \pm 0.46$ & $1.25 \pm 0.05$ & $25.9 \pm 6.00$ & $0.4 \pm 0.08$ & $36 \pm 2.07$ & $1171 \pm 376.90$ & $2.06 \pm 0.31$ & $1.11 \pm 0.13$ \\
\hline CSB $2 \%$ & $6.4 \pm 0.06$ & $1.74 \pm 0.27$ & $26.1 \pm 4.72$ & $0.5 \pm 0.06$ & $34 \pm 2.28$ & $1243 \pm 221.13$ & $1.87 \pm 0.21$ & $1.04 \pm 0.14$ \\
\hline CSB 5\% & $6.5 \pm 0.19$ & $1.81 \pm 0.07$ & $31.8 \pm 5.86$ & $0.6 \pm 0.11$ & $31 \pm 4.26$ & $1329 \pm 250.73$ & $1.85 \pm 0.04$ & $1.04 \pm 0.03$ \\
\hline
\end{tabular}




\section{CONCLUSIONS}

This experiment was conducted at a greenhouse of Chungnam National University in Daejeon, Korea, from December 28, 2016 to February 22, 2017, to investigate the properties of biochar derived from coffee sludge, a discarded domestic waste amounting to $700,000 \mathrm{t}$ per year. The biochar was applied as a soil amendment and the growth characteristics of Chinese cabbage in field soil and bed soil were evaluated through pot trials in a greenhouse.

1. In both field soil and bed soil, the chlorophyll and nitrate contents tended to decrease with increase in the amounts of coffee sludge biochar applied.

2. In field soil, the highest shoot fresh weight (116.46 \pm $1.3 \mathrm{~g} \mathrm{plant}^{-1}$ ) of Chinese cabbage was observed in $5 \%$ coffee sludge biochar, and shoot fresh weight increased by $9 \%$ compared to that in the control $\left(105.84 \pm 12.2 \mathrm{~g} \mathrm{plant}^{-1}\right)$. In bed soil, the highest shoot fresh weight $209.35 \pm 13.8 \mathrm{~g} \mathrm{plant}^{-1}$ ) of Chinese cabbage was observed in $2 \%$ coffee sludge biochar, and shoot fresh weight increased by $4 \%$ compared to that in the control $\left(200.87 \pm 41.1 \mathrm{~g} \mathrm{plant}^{-1}\right)$.

3. The growth characteristics of Chinese cabbage such as shoot fresh weight, number of leaves, leaf length, leaf width, and head height was more favorable in bed soil than in field soil because of attaining the optimal $\mathrm{pH}$ levels (6.0-6.5) required for the growth of Chinese cabbage by the addition of coffee sludge biochar.

4. The $\mathrm{pH}$ in both field soil and bed soil treated with coffee sludge biochar was higher than that in the control. This result supports the finding that application of coffee sludge biochar can improve acidic growing condition by increasing the $\mathrm{pH}$ of field soil and bed soil, as well as lowering the heavy metal content in soil, thereby regulating heavy metal uptake by plants.

5. The EC in field soil and bed soil treated with coffee sludge biochar tended to increase compared with the EC in the control. Nevertheless, the EC values were lower than the value $\left(2.0 \mathrm{dS} \mathrm{m} \mathrm{m}^{-1}\right)$ that is deleterious to the growth of Chinese cabbage.

6. The available phosphate, organic matter, and total nitrogen in both field soil and bed soil treated with coffee sludge biochar were higher than those in the control.

7. The exchangeable cation in coffee sludge biochar treatments in both field soil and bed soil was slightly decreased compared to control but it didn't shown a significant difference.

\section{AUTHOR CONTRIBUTIONS}

Hyeon-Ji SONG, Jae-Han LEE, Su-Hun KIM, and Ho-Cheol LEE carried out analysis and interpretation of data. Yoshiyuki SHINOGI verified the data. Taek-Keun $\mathrm{OH}$ supervised the project and wrote the paper. All authors commented on the manuscript.

\section{ACKNOWLEDGMENT}

This work was supported by Korea Institute of Planning and Evaluation for Technology in Food, Agriculture, Forestry and Fisheries (IPET) through "Agri-Bioindustry Technology Development Program", funded by Ministry of Agriculture, Food, and Rural Affairs (MAFRA) (Project No. 315026-3), and was financially supported by research fund of Chungnam National University.

\section{REFERENCES}

Ahmad, M, Lee, S. S., Dou, X., Mohan, D., J. K. Sung and J. E. Yang 2012 Effects of pyrolysis temperature on soybean stoverand peanut shell-derived biochar properties and TCE adsorption in water. Bioresour. Technol., 118: 536-544

Atkinson, C. J., J. D. Fitzgerald and N. A. Hipps 2010 Potential mechanisms for achieving agricultural benefits from biochar application to temperate soils: a review. Plant Soil., 337: 1-18

Back, J. H., Kim, B. J., W. C. Park and S. J. Kang 1999 Effects of Slow-Released Nitrogen Fertilizer Using Waste Paper Slurry on the Growth and Yield of Chinese Cabbage and Chemical Properties of Soil. Korean J. Eviron. Agric., 18(4): 327-331 [in Korean]

Cantrell, K. B., Hunt, P. G., Uchimiya, M., J. M. Novak and K. S. Ro 2012 Impact of pyrolysis temperature and manure source on physicochemical characteristics of biochar. Bioresour. Technol., 107: 419-428

Cater, S., Shackley, S., Sohi, S., T. B. Suy and S. Haefele 2013 The Impact of Biochar Application on Soil Properties and Plant Growth of Pot Grown Lettuce (Lactuca sativa) and Cabbage (Brassica chinensis). Agronomy., 3(2): 404-418

Cho, N. K., Kang, Y. K., Song, C. K., Cho, Y. I., B. K. Kang and M. R. Ko 2003 Effects of Worm Casting (100\%) Organic Fertilizer Rate on Growth Characters and Yield of Elgari Chinese Cabbage in Jeju Island. J. Subtropical Agri. \& Biotech., 19(2): 43-46 [in Korean]

Choi, Y. R. 2012 The Characteristics of the Biochar Produced from Waste Biomass for Improvement of Acidic Soils. Master Thesis, Kwangwoon University. Seoul, Korea. [in Korean]

Ha, H. S.,Kang, U. G., H. Lee and Y. B. Lee 1998 Effects of Fly Ash, Gypsum, and Shell on the Chemical Properties of Soil and Growth of Chinese Cabbage in Plastic Film Housed Paddy. Korean J. Eviron. Agric., 17(1): 65-69 [in Korean]

Ha, S. K., Kim, M. S., Ryu, J. S., Jo, G. L., Choi, S. C., Kim, Y. S., Choi, M. T., Ahn, B. K., Kim, H. W., Kim, C. Y., Y. H. Lee and S. H. Yang 2010 Monitoring of Chemical Properties for the Upland Soils in Korea, Korean J. Soil Sci. Fert., Symposium and presentation, 6-7 May 2010, Hongcheon, Korea [in Korean]

Ha, S. Y. 2015 Aerobic Composting of Wastewater Sludge Using Beneficial Microorganisms (BM). Ph. D. Thesis, Korea Maritime and Ocean University. Busan, Korea. [in Korean]

Han, K. H., Zhang, Y. S., Jung, K. H., Cho, H. R., M. J. Seo and Y. K. Sonn 2016 Statistically estimated storage potential of organic carbon by its association with clay content for Korean upland subsoil. Korean J. Agri. Sci., 43: 353-359. [In Korean]

Hong, S. D., Kim, K. I., H. T. Park and S. S. Kang 2001 Relationship between Leaf Chlorophyll Reading Value and Soil N-supplying Capability for Tomato in Green House. Korean J. Soil Sci. Fert., 34(2): 85-91 [in Korean]

Jung, S. H. 2014 Effects of Biochar Derived from Agricultural and Forest Residue on Carbon Sequestration and Soil Quality. Master Thesis, Kangwon National University. Chuncheon, Korea. [in Korean]

Kang, S. W., Kim, H. T., D. C. Seo and J. S. Cho 2016 Evaluation of Cabbage Growth under Different Application Levels of 
Biochar in Upland. Korean J. Soil Sci. Fert., Symposium and presentation, 10-11 March 2016, Seoul, Korea [in Korean]

Kim, B. M., Kang, C. H., Yang, J. K., Na, J. K., Jung, J. A., Jung, H. J., Lim, J. H., Ko, K. M., W. H. Kim and Y. Y. Chang 2012 Cu and Cd Sorption of the Biochar Derived from Coffee Sludge. J. Soil Groundw. Environ., 17(2): 87-100 [in Korean]

Koh, I. H., Kim, J. G., Kim, G. S., Park, M. S., D. M. Kang and W. H. Ji 2016 Stabilization of Agricultural Soil Contaminated by Arsenic and Heavy Metals using Biochar Derived from Buffalo Weed. J. Soil Groudw. Environ., 21(6): 87-100 [in Korean]

Kwapinski, W., Byrne, C. M. P., Kryachko, E., Wolfram, P., Adley, C., Leahy, J. J., E. H. Novotny and M. H. B. Hayes 2010 Biochar from Biomass and Waste. Waste Biomass Valor., 1(2): 177189

Lee, S. B., Lim, J. E., Lee, Y. J., Sung, J. K., D. B. Lee and S. Y. Hong 2016 Analysis of components and applications of major crop models for nutrient management in agricultural land. Korean J. Agri. Sci., 43: 537-546 [in Korean]

Lim, J. E., S. S. Lee and Y. S. Ok 2015 Efficiency of Poultry Manure Biochar for Stabilization of Metals in Contaminated Soil. J. Appl. Biol. Chem., 58(1): 39-50 [in Korean]

NAAS. 2010. Recommendation of the amount of fertilizer for crops. RDA. Juenju, Korea. [in Korean]

NAAS. 2012. Research and Analysis Criteria for crops. RDA. Juenju, Korea. [in Korean]

Novak, J. M., Busscher, W. J., Laird, D. A., Ahmedna, M., D. W. Watts and M. A. S. Niandou 2009 Impact of Biochar Amendment on Fertility of a Southeastern Coastal Plain Soil. Soil. Sci., 174(2): 105-112
Oh, T. K., Lee, J. H., S. H. Kim and H. C. Lee 2017 Effect of biochar application on growth of Chinese cabbage (Brassica chinensis). Korean J. Agri. Sci., 44: 359-365 [in Korean]

Spokas, K. A. and. D. C. Reicosky 2009 Impacts of Sixteen Different Biochars on Soil Greenhouse Gas Production. Ann. Environ. Sci.,3: 179-193

Upadhayay, K. P., George, D., R. S. Swift and V. Galea. 2014 The Influence of Biochar on Growth of Lettuce and Potato. $J$. Integr. Agric., 13(3): 541-546

Woo, S. H. 2013 Biochar for Soil Carbon Sequestration. Clean Tech., 19(3): 201: 211 [in Korean]

Woo, S. H. 2015 Biochar, Press, G-World (Korea), p. 176-181 [in Korean]

Yanai, Y., K., Toyota and M. Okazaki, 2007 Effects of Charcoal Addition on $\mathrm{N}_{2} \mathrm{O}$ Emissions from Soil Resulting from Rewetting Air-dried Soil in Short-term Laboratory Experiments. Soil Sci. Plant Nutr., 53(2): 181-188

Yoo, G. and H. Kang 2012 Effects of Biochar Addition on Greenhouse Gas Emissions and Microbial Responses in a Short-Term Laboratory Experiment. J. Environ. Qual., 41(4): 1193-1202

Yoon, H. S. 2012 Effects of Soil Amendments Manufactured with Coal Cobustion Ash on Soil Fertility and Crop Growth. Master Thesis, Kangwon National University. Chuncheon, Korea. [in Korean]

WIKITREE. 2015. The 6 Ways to Utilize Coffee Sludge by 120\%. [Online] Available: http://www.wikitree.co.kr/ -main/news_ view.php?id=213256 [2017 Oct 31] [in Korean] 